\title{
Synthesis and Characterization of $\mathrm{Tb}^{3+}$-Activated $\mathrm{TiO}_{2}$ Photoluminescence Nanomaterials \\ $\mathrm{Tb}^{3+}$ ile Aktive Edilmiş $\mathrm{TiO}_{2}$ Fotolüminesans Nanomalzemelerin Sentezi ve Karakterizasyonu
}

\author{
İdil Aritman $1^{*} \mathbb{C}$ \\ ${ }^{1}$ Department of Mechanical Engineering, Faculty of Engineering, Dokuz Eylül University, Izmir, TURKEY \\ Sorumlu Yazar / Corresponding Author*: idilaritman@gmail.com \\ Geliş Tarihi / Received: 20.03.2019 \\ Araștirma Makalesi/Research Article \\ Kabul Tarihi / Accepted: 31.12.2019 \\ DOI: $10.21205 /$ deufmd.2020226502 \\ Atıfsekli/How to cite: ARITMAN, I.(2020). Synthesis and Characterization on of Tb ${ }^{3+}$-Activated TiO $_{2}$ Photoluminescence Nanomaterials. \\ DEUFMD, 22(65), 325-330.
}

\begin{abstract}
As compared to other semiconductor photocatalysts, titanium dioxide has so far been shown to be the most promising material used for both fundamental research and practical applications, because it exhibits a higher photoreactivity and it is cheap, nontoxic, chemically and biologically inert, and photostable. Rare earth ions $\left(\mathrm{RE}^{3+}\right)$ are preferred as dopant elements due to their high densities and high light yields. $\mathrm{Tb}^{3+}$ doped $\mathrm{TiO}_{2}$ nanoparticles offer several advantages such as broad absorption band, high emission intensity, long lifetime, stability. TiO2: $1 \% \mathrm{~Tb}^{3+}$ nanoparticles, were produced at 550 degrees by the sol-gel method. Particle size analysis, XRD, DTA-TG, FTIR, SEM, and PL analyzes of the synthesized nanomaterials were performed. In the anatase crystal structure, the dimensions of the nanoparticles were measured below $100 \mathrm{~nm}$ and were observed in the microstructure where the particles were clustered in places. When the nanoparticles were excited at $275 \mathrm{~nm}$, green emission bands of $\mathrm{Tb}^{3+}$ ions at $544 \mathrm{~nm}$ and $585 \mathrm{~nm}$ were observed. This wavelength is attributed to electronic transitions ${ }^{5} \mathrm{D}_{4} \rightarrow{ }^{7} \mathrm{~F}_{5}$ and ${ }^{5} \mathrm{D}_{4} \rightarrow{ }^{7} \mathrm{~F}_{4}$, respectively.
\end{abstract}

Öz

Diğer fotokatalitik yarı iletkenlere kıyasla, titanyum dioksitin şimdiye dek hem temel araştırmalarda hem de pratik uygulamalarda kullanılan en umut verici malzeme olduğu gösterilmiștir, çünkü daha yüksek bir foto reaktivite sergiler ve ucuz, toksik olmayan, kimyasal ve biyolojik olarak etkisiz ve kararlıdır. Nadir toprak iyonları $\left(\mathrm{RE}^{3+}\right)$, yüksek yoğunlukları ve yüksek ışık verimleri nedeniyle dopant elementler olarak tercih edilir. $\mathrm{Tb}^{3+}$ katkılı $\mathrm{TiO}_{2}$ nanopartikülleri, geniş emme bandı, yüksek emisyon yoğunluğu, uzun ömür, stabilite gibi birçok avantaj sunar. Ti0 $0_{2}: \% 1 \mathrm{~Tb}^{3+}$ nanopartiküller soljel yöntemi ile $550^{\circ} C^{\prime}$ de üretildi. Sentezlenen nanomalzemelerin partikül boyut analizi, XRD, DTATG, FTIR, SEM ve PL (photo luminescence) analizleri yapılmıștır. Anataz kristal yapısında, nanopartiküllerin boyutları 100 nm'nin altında ölçülmüş ve partiküllerin yer yer kümelendiği mikroyapıda gözlenmiştir. Nanopartiküller $275 \mathrm{~nm}$ 'de uyarıldığında, $544 \mathrm{~nm}$ ve $585 \mathrm{~nm}^{\prime} \mathrm{de} \mathrm{Tb}^{3+}$ iyonlarının yeşil emisyon bantları gözlenmiștir. Bu dalga uzunluğu, sırasıyla ${ }^{5} \mathrm{D}_{4} \rightarrow{ }^{7} \mathrm{~F}_{5}$ and ${ }^{5} \mathrm{D}_{4} \rightarrow{ }^{7} \mathrm{~F}_{4}$ elektronik geçişlerine bağlanmaktadır.

Anahtar Kelimeler: $\mathrm{TiO}_{2}$, Foto Lüminesans, Sol-jel, Nadir Toprak Elementleri 


\section{Introduction}

Titanium dioxide $\left(\mathrm{TiO}_{2}\right)$ nanoparticles are widely used in fields such as pigments, photovoltaic cells, photocatalysis, gas sensors, and innovative surface coating materials due to their photochemical and electrochemical properties [1,2]. Because of its stable and durable structure, wide use area and low cost, studies on the development of $\mathrm{TiO}_{2}$ are continuously going on [3]. Also, $\mathrm{TiO}_{2}$ is usually used as a raw material because it can be in both rutile and anatase phase structure [4,5]. Rare earth element activated oxide nanoparticles are of interest because of their tunable and improved optical properties. Lanthanide ions have high density and light output. It increases the UV absorption capacity and emission intensity of photoluminescent and photocatalytic materials. In this way, they make it a more efficient material. The photoluminescence properties can be adjusted by selecting the appropriate host matrix and additive material and determining the stoichiometric additive ratios [6,7]. TiO2 nanoparticles can be produced by different methods such as sol-gel, flame spray pyrolysis, hydrothermal synthesis, solvothermal synthesis, and emulsion precipitation [8]. $\mathrm{Tb}^{3+}$ ions are photoluminescen ions that showdown conversion characteristics. Tbactivated oxide nanoparticles absorb highenergy photons and emit low-energy photons, that is, emit in the UV region of the electromagnetic spectrum and propagate through the visible and infrared region. These nanomaterials also exhibit another phenomenon known as quantum cutting whereby a single high-energy photon is absorbed to produce two photons of lower energy [9].

Some rare earth doped $\mathrm{TiO}_{2}$ materials have been studied in the literature. A. Xu et al. have found that rare-earth dopamine increases photocatalytic activity. The increase in activity was due to higher adsorption, redshifts and electron-hole recombination prevention[10]. J. Liqiang et al. investigated the effect of $\mathrm{La}^{3+}$ addition on $\mathrm{TiO}_{2}$. The results showed that $\mathrm{La}^{3+}$ dopant had a great inhibition on $\mathrm{TiO}_{2}$ phase transformation, and did not give rise to a new PL signal, but it could improve the intensity of PL spectra with an appropriate $\mathrm{La}^{3+}$ content, attributed to the increase in the content of surface oxygen vacancies and defects [11]. X. Lu et al. investigated the effect of $\mathrm{Nb}^{3+}$ addition on $\mathrm{TiO}_{2}$. After $\mathrm{Nb}^{3+}$ doping, the anatase structure was retained and a new absorption peak was observed in FTIR spectrum. The $\mathrm{Nb}^{3+}$ doping leads to a significant increase in powder conductivity. As expected, an overall 7.8\% energy-conversion efficiency was obtained for $\mathrm{Nb}^{3+}$ - dopedTiO2, which was an improvement of $18.2 \%$ relative to that of the undoped material [12]. A. Patra et al. investigated the effect of $\mathrm{Er}^{3+}$ addition on $\mathrm{TiO}_{2}$. According to their results, the $\mathrm{Er}^{3+}$ ions concentration increases, the emission intensity increases [13]. V. Šteng and his colleaguesproduced different rare earth ions doped $\mathrm{TiO}_{2}$ particles by sol-gel method. Photocatalytic activity under UV or visible light beams has significantly increased with rare earth ions addition. The increase in photocatalytic activity was due to higher adsorption and electron transfer of rare earth ions to $4 \mathrm{f}$. The highest increase in photoactivity was obtained at $0.5-1 \%$ rare earth ion doping, which may be due to the most efficient separation of load carriers. In this study, Tb iondoped $\mathrm{TiO}_{2}$ nanoparticles were produced by the sol-gel method. It is expected that the photoluminescence and photocatalytic yield will be very high because the $\mathrm{Tb}^{3+}$ element is a lanthanide element with a high number of unpaired electrons in the $4 \mathrm{f}$ orbitals. $\mathrm{TiO}_{2}$ nanoparticles were synthesized at $550^{\circ} \mathrm{C}$ in the air with a $1 \% \mathrm{~Tb}^{3+}$ ion content and characterized structurally and microstructurally. The size and distribution of the produced particles have been studied. After characterization using XRD, SEM, FTIR, DTA-TG and PL Spectra devices, the results were evaluated.

\section{Material and Method}

Titanium (IV) isopropoxide (TTIP, $\left.\mathrm{Ti}\left[\mathrm{OCH}\left(\mathrm{CH}_{3}\right)_{2}\right]_{4}, 97 \%\right)$, Terbium (III) nitrate pentahydrate $\mathrm{Tb}\left(\mathrm{NO}_{3}\right) 3.5 \mathrm{H}_{2} \mathrm{O}>99 \%$, distilled water, citric acid and polyethylene glycol (PEG) were purchased from Sigma-Aldrich. All of the used chemicals were in analytical grade and used directly without further purification. For the 0.1 molar solution, 0.0099 moll TTIP, 0.0001 moll $\mathrm{Tb}$ precursor and $100 \mathrm{~mL}$ purified water were prepared. TTIP and distilled water in a balloon jug were mixed mechanically for 30 minutes. A separate beaker Tb precursor was dissolved in distilled water. In another beaker, citric acid solution was prepared in pure water to adjust the solution ph. All the prepared 
solutions joined together. The $\mathrm{pH}$ of the solution was measured as 3.05 . The final solution was added 1.5 grams of PEG and the prepared solution was left to stand at 100 degrees for gelation. After the gelation was completed, drying was performed at 275 degrees.

The obtained gels were characterized by the Fourier Transform Infrared (FTIR) device for the detection of organic bonds. In addition, to determine the calcination temperature of the obtained jellies, thermal analysis was performed using Differential Thermal Analysis/Thermo-gravimetric (DTA-TG) device, which allows to identify endothermic and exothermic reactions. According to the DTA results, the sintering temperature was determined to be $550^{\circ} \mathrm{C}$ and the dried powders were heat-treated at $550^{\circ} \mathrm{C}$ in air for 2 hours. After the calcination process was completed, structural and microstructural analyzes of $\mathrm{TiO}_{2}: 1 \% \mathrm{~Tb}^{3+}$ nanoparticles were performed.

The Malvern Zeta Sizer ZS90 nano particle size measurement device was used for particle size and distribution analysis. In addition, phase analysis and crystal structure determination were performed by Thermo-Scientific ARL-K $\alpha$ X-ray diffractometer (XRD). The microstructures of the nanoparticles were carried out at $100 \mathrm{kX}$ magnification and $5 \mathrm{kV}$ accelerating voltage using FEI Nova Nano SEM 650. Steady-state photoluminescence (PL) measurements were recorded on a redsensitive photomultiplier tube equipped with a spectrofluorometer. The instrument was equipped with a Standard 15W Xe lamp and a microsecond flash lamp for steady state measurements.

\section{Results}

$\mathrm{PH}$ value is an important value that determines the acidic or basic character of the solution. The $\mathrm{pH}$ value of the solution significantly influences the gelation rate of the solution and the polymeric chain structures formed during gelation. $\mathrm{pH}$ is an important factor for many chemical treatments such as the solubility of the compound, the rate of a reaction. The $\mathrm{pH}$ of the $\mathrm{TiO}_{2}$-based solution was measured in the solution state. The solution shows an acidic character due to the $\mathrm{pH}$ value of 3.05 .

FTIR analysis was performed to gain more insight into the structure and the composition of the synthesized products. Fourier transformed infrared (FTIR) analysis of the sample was conducted in the wavenumber range of 500$4000 \mathrm{~cm}^{-1}$. Figure 1 shows the FTIR spectra of the xerogel and its calcined products, respectively. The sharp peaks seen in the form of vibration between the values of 3856-3639 $\mathrm{cm}^{-1}$ wavenumbers are $0-\mathrm{H}$ stretches of medium force. The strong and broadband between the values of $3580-3290 \mathrm{~cm}^{-1}$ wavenumbers are $\mathrm{O}-\mathrm{H}$ stresses intermolecular connected. The broadband between the values of 2980-1650 $\mathrm{cm}^{-1}$ wavelength refers to strong and weak $\mathrm{C}-\mathrm{H}$ bonds. However, there may be N-H stresses between these values. Between the values of $1450-940 \mathrm{~cm}^{-1}$ wavenumbers, sharp and strong bonds can be strong bonds of C-O. There may be strong C-N aromatic stresses. Sharp and strong peaks at wavenumbers of $962 \mathrm{~cm}^{-1}$ and 839 $\mathrm{cm}^{-1}$ can be attributed to $\mathrm{C}=\mathrm{C}$ bonds. The broadband at $650 \mathrm{~cm}^{-1}$ wavenumbers can be attributed to Ti-O-Ti bonds.

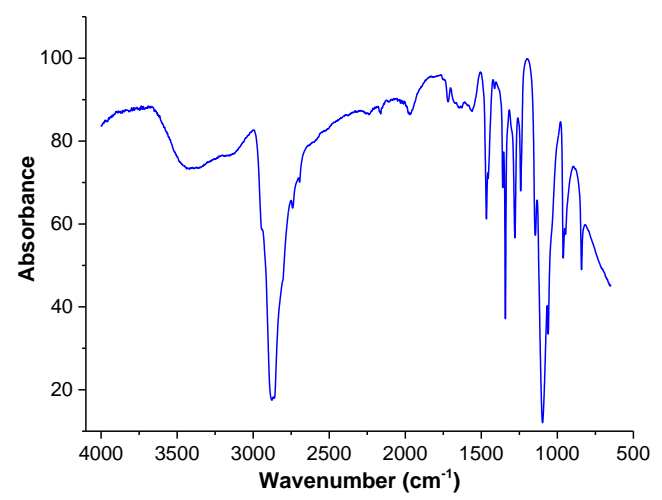

Figure 1. FTIR analysis of $\mathrm{TiO}_{2}: 1 \% \mathrm{~Tb}^{3+}$ xerogel

DTA-TGA is an extremely important analysis to see the endothermic and exothermic reactions associated with temperature increase in the material. Weight loss due to temperature increase is also determined by this analysis. In this context, all solutions were dried at $100{ }^{\circ} \mathrm{C}$ for several hours until gelation and xerogels were formed, and then DTA-TGA analysis was carried out in nitrogen gas at temperatures range of $25-800^{\circ} \mathrm{C}$. The DTA-TGA curve of $\mathrm{TiO}_{2}-$ based gels are shown in Figure 2. 


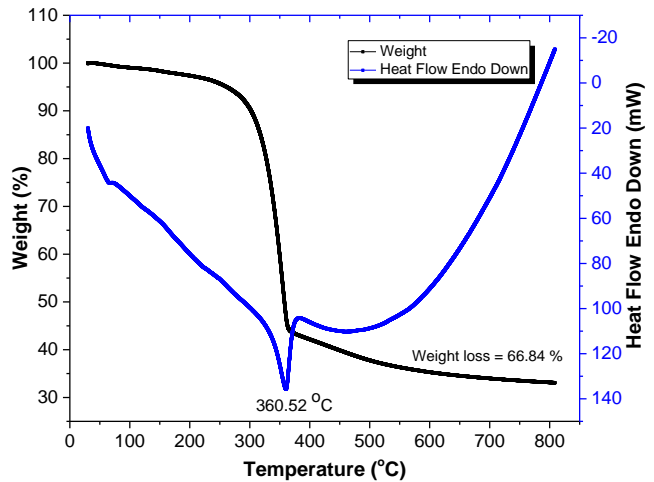

Figure 2. DTA-TG analysis of $\mathrm{TiO}_{2}: 1 \% \mathrm{~Tb}^{3+}$ nanoparticles

As can be seen, 66.84 percent of the total mass was removed from the structure. As the temperature increase, the physical water had gone away prior from the structure. The carboxyl and nitrate forms in the precursors are then evaporated. Lastly, the $\mathrm{TiO}_{2}$ anatase structure has formed at about 360 degrees. DTA analysis is very useful for producing nanoparticles in the smallest possible size since at high temperatures the grain will grow in the microstructure.

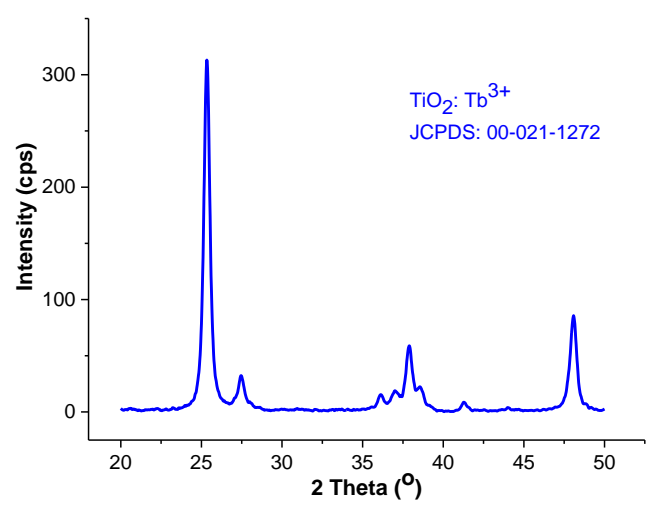

Figure 3. XRD analysis of $\mathrm{TiO}_{2}: 1 \% \mathrm{~Tb}^{3+}$ nanoparticles

XRD patterns of the produced $\mathrm{TiO}_{2}: 1 \% \mathrm{~Tb}^{3+}$ luminescent nanoparticles are presented in Figure 3. All diffraction peaks are identical to those of the pure anatase phase without the presence of another polymorph. Heat treatment of X-ray diffraction peaks for calcined powder showed the growth of crystals during calcination [14]. In Figure 3, XRD patterns exhibited strong diffraction peaks at $25^{\circ}, 27^{\circ}, 37^{\circ}$ and $48^{\circ}$ indicating $\mathrm{TiO}_{2}$ in the anatase phase.

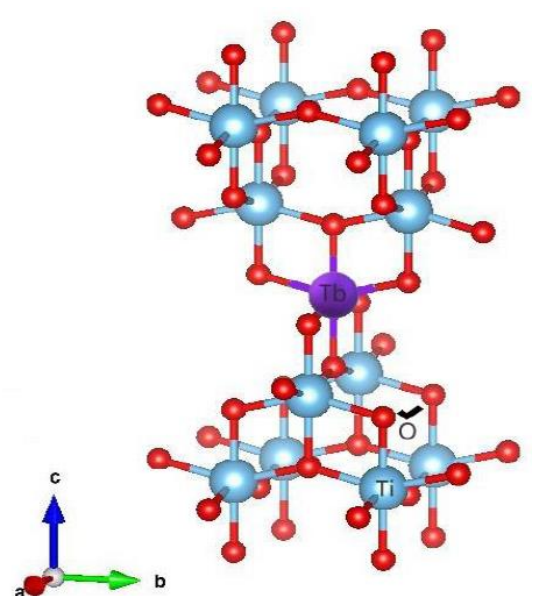

Figure 4. Crystal structure of anatase $\mathrm{TiO}_{2}$ doped with $\mathrm{Tb}^{3+}$

All the peaks are in good agreement with the standard spectrum (JCPDS no.: 00-0211272). Also in Figure 4 shows that the $\mathrm{Tb}$ doped $\mathrm{TiO}_{2}$ nanoparticles are identified to have a textured tetragonal anatase crystal structure. The crystal structure is tetragonal and is included in the "I 41/a $\mathrm{m} \mathrm{d"} \mathrm{space} \mathrm{group.}$ Also $\mathrm{TiO}_{2}$ lattice parameters were measured as

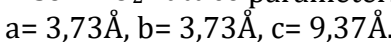

SEM was used to further examine the particle size, crystallinity, and morphology of samples. Figure 5 shows SEM images of anatase $\mathrm{TiO}_{2}$ : $1 \% \mathrm{~Tb}^{3+}$ nanoparticles. In these nanoparticles, many anatase agglomerates can be seen by SEM observation.

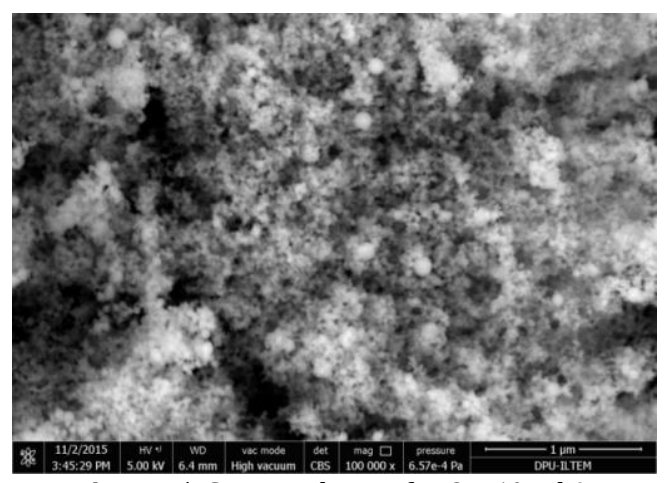

Figure 5. SEM analysis of $\mathrm{TiO}_{2}: 1 \% \mathrm{~Tb}^{3+}$ nanoparticles

The particle of $\mathrm{TiO}_{2}: 1 \% \mathrm{~Tb}^{3+}$ nanoparticles in anatase phase is mostly spherical morphology. It is believed that the 
luminescence efficiency of the particles depends on the particle size. Because, in the literature research, the quantum effect becomes active as the particle size becomes smaller [15].

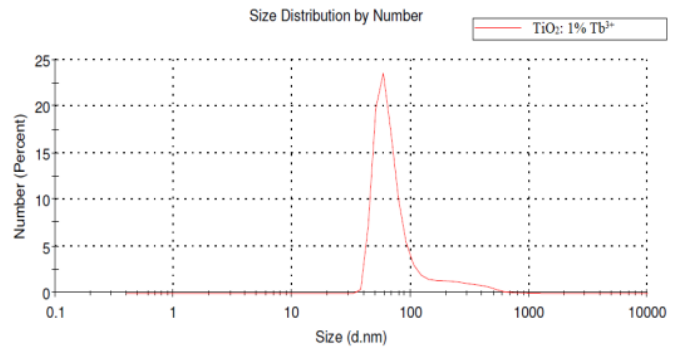

Figure 6. Particle size measurement results of $\mathrm{TiO}_{2}: 1 \% \mathrm{~Tb}^{3+}$ nanoparticles

Figure 6 shows the particle size measurement results. Using the sol-gel method, it is observed that the nanosize material is produced successfully. Size is a very crucial factor in developed materials. When the size analysis outcomes are examined, we can distinctly see that the nanoparticles are below $100 \mathrm{~nm}$.

The size of the nanoparticles provides significant efficiency in the chemical and physical properties of these materials. Surface area and surface energy increase. The increase in surface energy and mobility of electrons results in a quantum effect on the material.

This means that the sol-gel method is an optimal method for nanoparticle production. In addition,

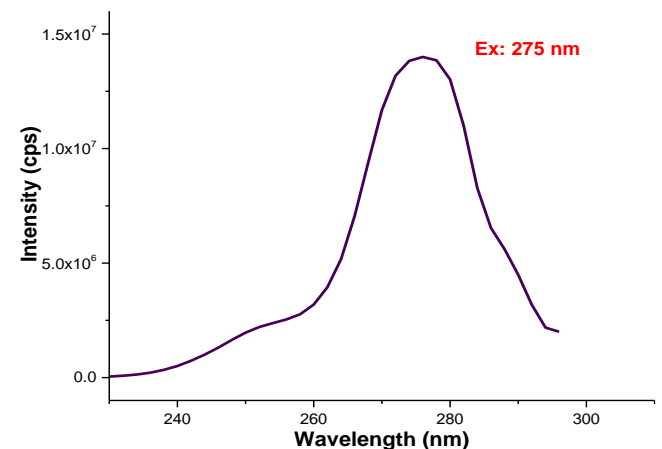

(a) the size of the calcined nanoparticles can easily be reduced by using nano grinder or by forging processes.

$\mathrm{Tb}^{3+}$ ions have a positive effect on $\mathrm{TiO}_{2}$ luminescence. Transfer of energy to the luminescent centers takes place between the $\mathrm{Tb}$ $\mathrm{O}$ - $\mathrm{Ti}$ bonds and the $\mathrm{Tb}-\mathrm{OH}$ bonds acting as extinguishants for luminescence. Tb-doped $\mathrm{TiO}_{2}$ nanoparticles exhibited green photoluminescence under excitation at $275 \mathrm{~nm}$. The presence of lanthanides in the titanium oxide matrix provides attractive optical properties for long-running multi-band work. They also offer high photostability, a narrow emission band, and a broad absorption band.

Under $276 \mathrm{~nm}$ excitation, the emission spectra of $\mathrm{Tb}^{3+}$ ions showed dark green, light green and yellow emission at $544 \mathrm{~nm}, 585 \mathrm{~nm}$ and $616 \mathrm{~nm}$, respectively (as shown in Figure 7).

The energy transitions in these regions depend on ${ }^{5} \mathrm{D}_{4} \rightarrow{ }^{7} \mathrm{~F}_{\mathrm{I}}(\mathrm{J}=5,4,3)$. The emission spectra have the highest dark green emission band corresponding to the ${ }^{5} \mathrm{D}_{4} \rightarrow{ }^{7} \mathrm{~F}_{5}$ transition at 544 $\mathrm{nm}$. Then, the light green emission band at $585 \mathrm{~nm}$ belongs to ${ }^{5} \mathrm{D}_{4} \rightarrow{ }^{7} \mathrm{~F}_{4}$, the yellow emission at 616 $\mathrm{nm}$ belongs to the ${ }^{5} \mathrm{D}_{4} \rightarrow{ }^{7} \mathrm{~F}_{3}$ transition. The blue emission peak at about $488 \mathrm{~nm}$ of the $\mathrm{Tb}^{3+}$ ion was not observed because it was associated with Raman scattering in our study. However, the ${ }^{5} \mathrm{D}_{4} \rightarrow$ ${ }^{7} F_{6}$ energy transition of this blue emission has been repeatedly shown in the literature [16-18].

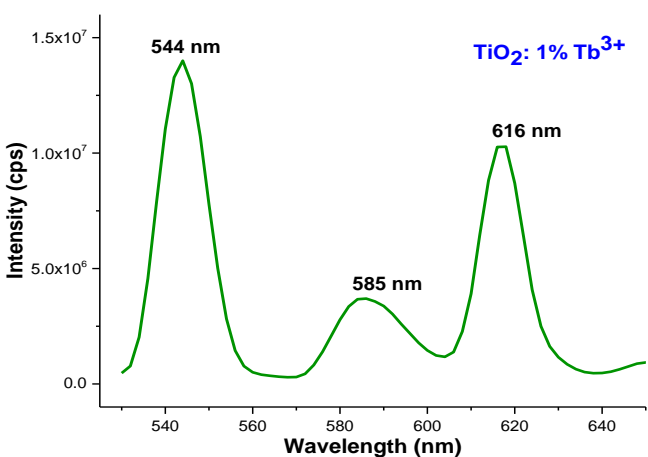

(b)

Figure 7. (a) Excitation spectrum of $\mathrm{TiO}_{2}: 1 \% \mathrm{~Tb}^{3+}$ nanoparticles, (b) Emission spectrum of $\mathrm{TiO}_{2}$ : $1 \% \mathrm{~Tb}^{3+}$ nanoparticles 


\section{Discussion and Conclusion}

In this study, $\mathrm{TiO}_{2}$ fluorescent particles were successfully produced by the sol-gel method by activating with $\mathrm{Tb}^{3+}$ rare earth ions. Structural and microstructural properties of the produced nanoparticles were studied by using XRD, FTIR, DTA-TG, SEM and PL spectra devices. Particle size measurement and morphological analysis showed that the particle size was below $100 \mathrm{~nm}$. The calcination temperature determined by the

\section{References}

[1] Dastjerdi R and Montazer M 2010. A review on the application of inorganic nanostructured materials in the modification of textiles: focus on anti-microbial properties Colloids Surfaces B Biointerfaces 79 5-18. DOI: 10.1016/j.colsurfb.2010.03.029

[2] Varghese O K, Paulose M, LaTempa T J, and Grimes C A 2009 High-rate solar photocatalytic conversion of $\mathrm{CO}_{2}$ and water vapor to hydrocarbon fuels Nano Lett. 9 731-7. DOI: 10.1021/nl803258p

[3] Schneider J, Matsuoka M, Takeuchi M, Zhang J, Horiuchi Y, Anpo M, and Bahnemann D W 2014 Understanding $\mathrm{TiO}_{2}$ photocatalysis: mechanisms and materials Chem. Rev. 114 9919-86. DOI: $10.1021 / \operatorname{cr} 5001892$

[4] Carp O, Huisman C L, and Reller A 2004 Photoinduced reactivity of titanium dioxide. Progress Solid-State Chemical 32, 33-177. DOI:10.1016/j.progsolidstchem.2004.08.001

[5] Zhang $\mathrm{H}$ and Banfield J F 2000 Understanding polymorphic phase transformation behavior during growth of nanocrystalline aggregates: insights from $\mathrm{TiO}_{2}$ J. Phys. Chem. $B \quad 104$ 3481-7. DOI: 10.1021/jp000499j

[6] Ahmed S. N. 2015. Physics and Engineering of Radiation Detection. Academic Press- ELSEVIER. 764 s.

[7] Weber E M J, Dotsenko a V, Glebov L B, and Tsekhomsky V a 2003 Handbook of Optical Laser and Optical Science and Technology Series Physics and Chemistry of Photochromic Glasses vol 23.

[8] Kango S, Kalia S, Celli A, Njuguna J, Habibi Y and Kumar R 2013 Surface modification of inorganic nanoparticles for development of organic-inorganic nanocomposites-A review Prog. Polym. Sci. 38 1232-61. DOI: 10.1016/j.progpolymsci.2013.02.003

[9] Yang, T. T. T. (Ed.). 2012. Rare Earth Nanotechnology. CRC Press. 249s.

[10] Xu A-W, Gao Y and Liu H-Q 2002 The preparation, characterization, and their photocatalytic activities of rare-earth-doped $\mathrm{TiO}_{2}$ nanoparticles J. Catal. 207 151-7. DOI: $10.1006 /$ jcat.2002.3539

[11] Liqiang J, Xiaojun S, Baifu X, Baiqi W, Weimin C and Honggang F 2004 The preparation and characterization of La-doped $\mathrm{TiO}_{2}$ nanoparticles and their photocatalytic activity J. Solid State Chem. 177 3375-82. DOI: 10.1016/j.jssc.2004.05.064

[12] Lu X, Mou X, Wu J, Zhang D, Zhang L, Huang F, Xu F and Huang $S 2010$ Improved-performance dyesensitized solar cells using Nb-doped $\mathrm{TiO}_{2}$ electrodes: efficient electron injection and transfer sol-gel method and DTA analysis was found to be successful in nanoparticle production. Energetic transitions of $\mathrm{Tb}^{3+}$ ions were detected by photoluminescence characterization $\left({ }^{5} \mathrm{D}_{4} \rightarrow{ }^{7} \mathrm{~F}_{\mathrm{J}}(\mathrm{J}\right.$ $=5,4,3)$ ). Tb-doped $\mathrm{TiO}_{2}$ shows the highest activity among all the rare earth doped samples investigated in the literature due to the increase in the electron transfer rate at the interface. This indicates that the photochemical process is dominated by electron-hole recombination.

Adv. Funct. Mater. 20 509-15. DOI: 10.1002/adfm.200901292

[13] Patra A, Friend C S, Kapoor R and Prasad P N 2003 Fluorescence upconversion properties of $\mathrm{Er}^{3+}$-doped $\mathrm{TiO}_{2}$ and $\mathrm{BaTiO}_{3}$ nanocrystallites Chem. Mater. 15 3650-5. DOI: $10.1021 / \mathrm{cm} 020897 \mathrm{u}$

[14] Wang J, Polleux J, Lim J and Dunn B 2007 Pseudocapacitive contributions to electrochemical energy storage in $\mathrm{TiO}_{2}$ (anatase) nanoparticles $\mathrm{J}$. Phys. Chem. C 111 14925-31. DOI: $10.1021 / \mathrm{jp} 074464 \mathrm{w}$

[15] Wang Y and Herron N 1991 Nanometer-sized semiconductor clusters: materials synthesis, quantum size effects, and photophysical properties $J$. Phys. Chem. 95 525-32.

[16] Souza A S, Nunes L A, Felinto M, Brito H F and Malta O L 2015 On the quenching of trivalent terbium luminescence by ligand low lying triplet state energy and the role of the 7F5 level: The [Tb $(\mathrm{tta})_{3}\left(\mathrm{H}_{2} \mathrm{O}\right)_{2}$ ] case J. Lumin. 167 167-71. DOI: 10.1016/j.jlumin.2015.06.020

[17] Đorđević V, Milićević B and Dramićanin M D 2017 Rare Earth-Doped Anatase $\mathrm{TiO}_{2}$ Nanoparticles Titanium Dioxide (InTech). DOI: 10.5772 /intechopen.68882

[18] Zheng C, Teng C P, Yang D-P, Lin M, Win K Y, Li Z and Ye E 2017 Fabrication of luminescent $\mathrm{TiO}_{2}$ : $\mathrm{Eu}^{3+}$ and $\mathrm{ZrO}_{2}: \mathrm{Tb}^{3+}$ encapsulated PLGA microparticles for bioimaging application with enhanced biocompatibility Mater. Sci. Eng. C. DOI: 10.1016/j.msec.2017.10.005 